\title{
Novel One-pot Synthesis of Thiazolo[3,2-a] Pyrimidin-5-one as a Key Compound for Poly Nuclear Heterocycles
}

\author{
A.M. Gaafar", A.S. Aly, Khadiga M. Abu-Zied, Shimaa A. \\ Gabal and M. EL-B. Shaban* \\ Department of Photochemistry, (Heterocyclic Unit), National \\ Research Centre and *Department of Chemistry, Faculty of \\ Science, Ain Shams University, Cairo, Egypt.
}

\begin{abstract}
3 -AMINO-2- hydroxy-7-methyl- thiazolo[3,2-a]pyrimidin-5-one (5) was synthesized by one-pot reaction from 2-bromo cyanoacetamide, ethyl acetoacetate and thiourea. The new 3-amino-2hydrazino derivatives $(15,18), 2$-pyrazol- thiazolo $[3,2-a]$ pyrimidin 5-ones $(14,17,20)$ and 2-(4-arylidene) -pyrazol-thiazolo [3,2-a] pyrimidin-5-ones (22a-d) were synthesized through facile condensing procedures starting from 3-amino-2-hydrazino-7-methyl-thiazolo[3,2a]pyrimidin-5-one (12). The newly synthesized products were characterized by their IR, ESI-MS, NMR and micro analytical data.
\end{abstract}

Keywords: Thiazolo [3,2-a] pyrimidin-5-one, One pot synthesis, Condensation, Intramolecular Cyclization and Tautomerism.

Thiazolopyrimidines are bicyclic heterocycles, formed by the reaction of 1,2dielectrophiles with a pyrimidin-2(1H)-thione skeleton ${ }^{(1-4)}$. They receive diverse pharmacological applications such as anti-HIV ${ }^{(5,6)}$, antibacterial ${ }^{(7,8)}$, anticancer ${ }^{(9)}$, anti-inflammatory $^{(10-12)}$, antimalarial ${ }^{(5)}$, antimicrobial ${ }^{(12,13)}$, anti-HSV-1 ${ }^{(14)}$ and herbicidal ${ }^{(15)}$ activities. Furthermore, some thiazolopyrimidines have been assigned as new acetylcholin esterase inhibitors, especially for the treatment of Alzheimer's disease $^{(16)}$. The aim of our study is to synthesis 3-amino-2-hydroxy-7- methylthiazolo[3,2-a]pyrimidin-5-one (5) to use it for the preparation of the 3-amino-2hydrazino derivative (12).

\section{Discussion}

Compound 5 is produced via one-pot synthesis of 2-bromocyanoacetamide, ethyl acetoacetate and thiourea in ethoxide solution via the intermediate 3 amino-3-hydroxy-2-(4-methyl-6-oxo-1,6-dihydro-pyrimidin-2-ylsulfanyl)-acrylo nitrile (2) (Scheme 1, Path A). Path B is considered to be a possible alternative to produce the final product 11 through the intermediate 8 . We have reasons to believe that the reaction mechanism obeyes path $A$ to form the intermediate 2 , which undergoes intramolecular cyclization at N3 to produce the cyclized intermediate 3 . In the presence of strong basic medium, the latter intermediate undergoes hydrolysis followed by elimination of amido group to furnish the final fused pyrimidine system (cf. 5). 


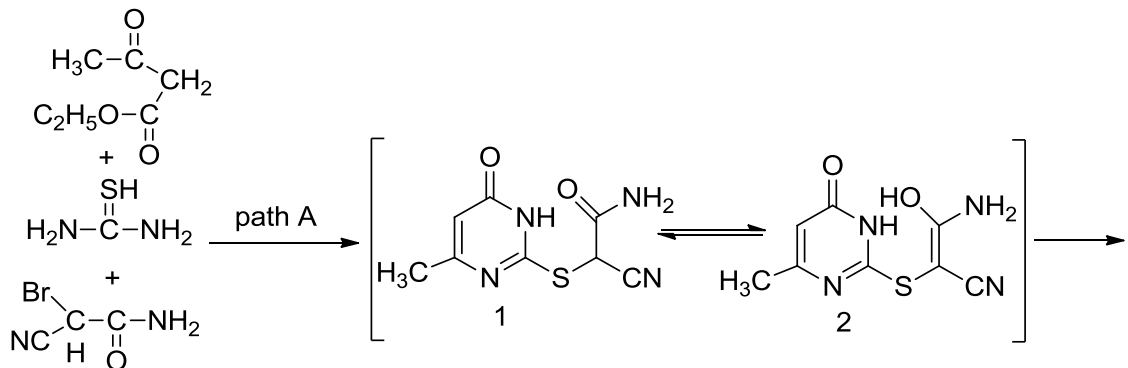

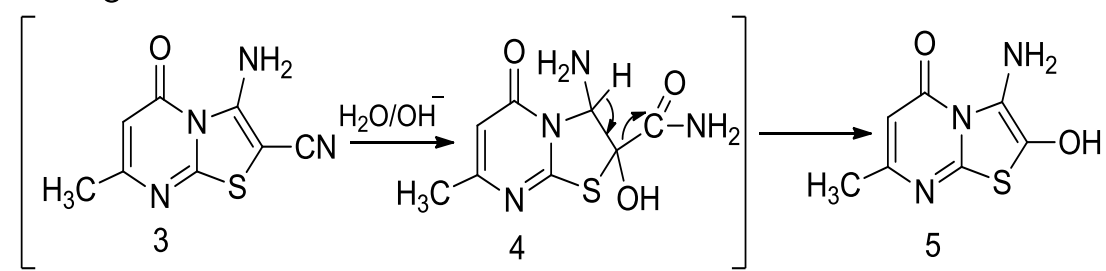

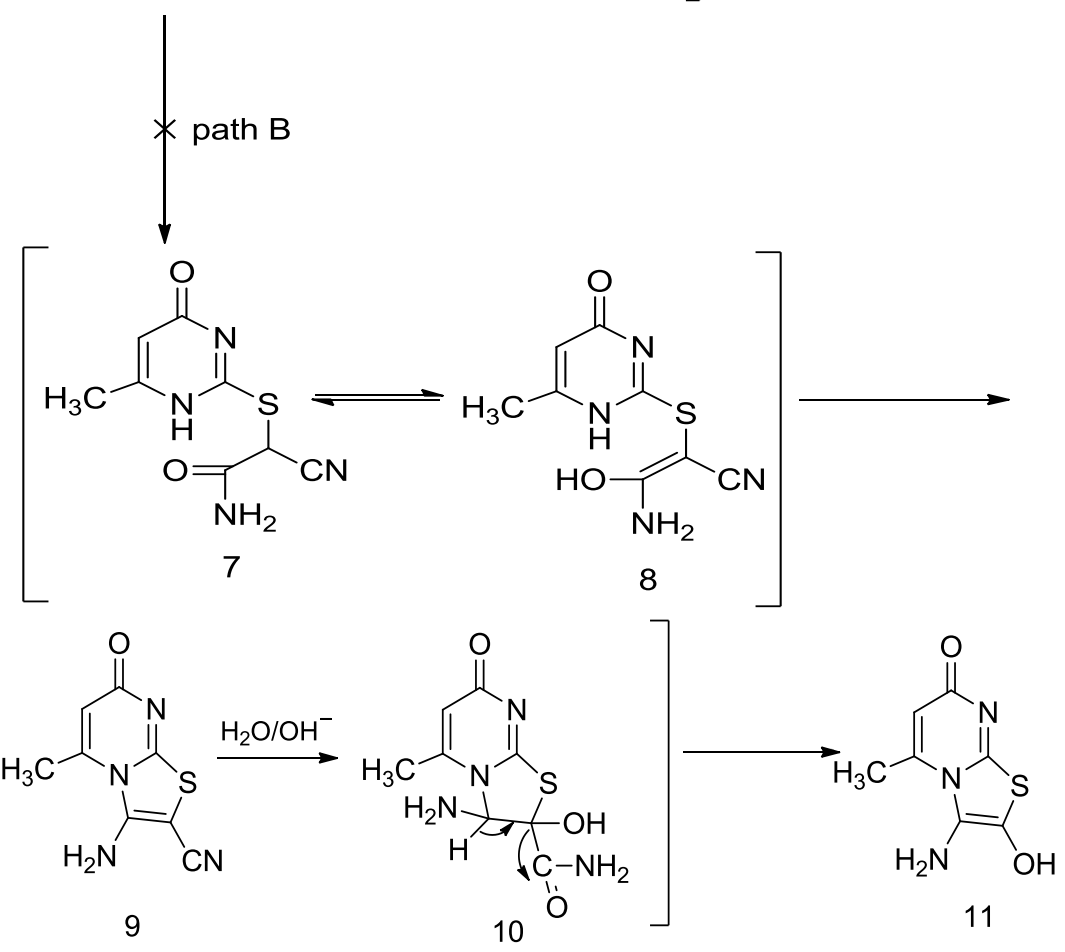

Scheme 1. Mechanistic pathway leading to the synthesis of 3-amino-2-hydroxy-7methyl-thiazolo[3,2-a] pyrimidin-5-one (5) and not to 3-amino-2-hydroxy5-methyl-8,8a-dihydro-thiazolo[3,2-a]pyrimidin-7-one (11) . 
Our assumption is based upon two facts; firstly, our previous experience in the synthesis of fused pyrimidines including thiazolopyrimidines ${ }^{(17)}$ and thienopyrimidines ${ }^{(18,19)}$. Secondly, literature survey which disclosed that N3 is the prime position for hetero cyclization in acidic or basic media ${ }^{(20-21)}$. The presence of an equilibrium between the two tautomeric structures of keto and enol forms (Scheme 2) is based on the spectral analyses. The ${ }^{1} \mathrm{H}-\mathrm{NMR}$ spectrum revealed a singlet signal integrated for one proton at $03.20 \mathrm{ppm}$ attributed to methine proton of the thiazolone ring of the keto form 6 . The spectrum also exhibited one $\mathrm{D}_{2} \mathrm{O}$ exchangeable singlet signal integrated for one proton at $\delta 10.8 \mathrm{ppm}$ attributed to $\mathrm{OH}$ group of the enol form 5. The IR spectrum displayed bands at $3766 \mathrm{~cm}^{-1}$ corresponding to broad $\mathrm{OH}$ group of the enol form 5 and at $1716 \mathrm{~cm}^{-1}$ corresponding to $(\mathrm{C}=\mathrm{O})$ of the thiazolone ring of the keto form 6 . The electron impact mass spectrum of compound 5 showed a peak at $\mathrm{m} / z 198(5 \%)$ corresponding to $\left(\mathrm{M}^{+}+1\right)$.<smiles>Cc1cc(=O)n2c(n1)SC(=O)[C@H]2N</smiles>

Scheme 2. The keto-enol type of tautomerism.

The strategies adopted for the synthesis of the new compounds are depicted in Schemes (3-10).

Scheme 3 comprises the direct hydrazinolysis of compound 5 with hydrazine hydrate to give the corresponding 3-amino-2-hydrazino-7-methyl-thiazolo[3,2-a] pyrimidin-5-one (12). Structure of compound 12 is confirmed on the basis of elemental analyses and spectral data. The electron impact mass spectrum of compound 12 showed a peak at $m / z, 212(7 \%)$ corresponding to $\left(\mathrm{M}^{+}+1\right)$. The ${ }^{1} \mathrm{H}-$ NMR spectrum exhibited one $\mathrm{D}_{2} \mathrm{O}$ exchangeable singlet signal integrated for two protons at $\delta 04.45 \mathrm{ppm}$ attributed to broad $\mathrm{NH}_{2}$ group of the thiazolone ring and a $\mathrm{D}_{2} \mathrm{O}$ exchangeable broad signal integrated for three protons at $\delta 08.7 \mathrm{ppm}$ attributed to $\mathrm{NH}+\mathrm{NH}_{2}$ groups. The IR spectrum revealed the absence of $\mathrm{OH}$ group and displayed bands at $3105 \mathrm{~cm}^{-1}$ corresponding to broad $\mathrm{NH}$ group and bands at $3426,3337 \mathrm{~cm}^{-1}$ corresponding to broad $2 \mathrm{NH}_{2}$ groups.

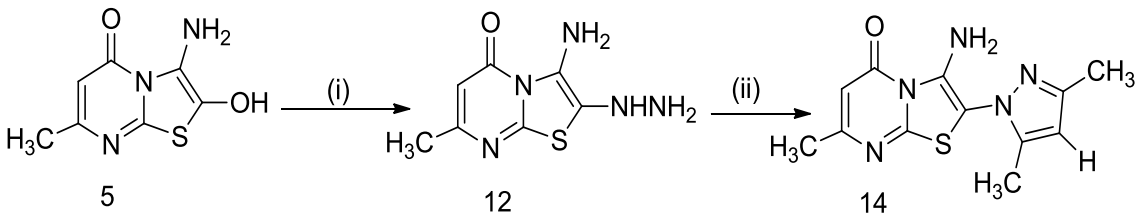

Scheme 3. Synthetic pathways for compounds 12 and 14. Reagents \& conditions: i: Hydrazine hydrate 99\%/ acetic acid $(1 \mathrm{ml})$ / abs. ethanol/reflux; ii: Pentan2,4-dione/ dry dioxane/ reflux.

Egypt. J. Chem. 59, No.3 (2016) 
Scheme 4 shows the tautomerism in compound 12 which is based on the spectral data. The ${ }^{1} \mathrm{H}-\mathrm{NMR}$ spectrum of compound 13 revealed a singlet signal integrated for one proton at $\delta 02.07 \mathrm{ppm}$ attributed to methine proton of the thiazol ring.

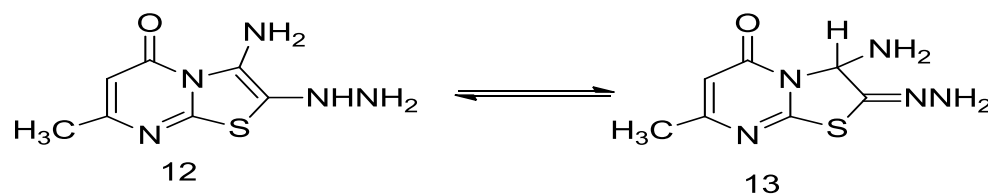

Scheme 4. The tautomerism of the two forms 12 and 13.

3-Amino-2-(3,5-dimethyl-pyrazol-1-yl)-7-methyl-thiazolo[3,2-a]pyrimidin-5one (14) (Scheme 3) was obtained in good yield by condensing compound 12 with an equimolecular amount of pentan-2,4-dione. Structure of compound 14 was confirmed on the basis of elemental analyses and spectral data. The ${ }^{1} \mathrm{H}-\mathrm{NMR}$ spectrum of 14 revealed two singlet signals each integrated for three protons at $\delta$ $02.15,02.19 \mathrm{ppm}$ attributed to the two $\mathrm{CH}_{3}$ groups of the pyrazole ring. In addition, a singlet signal integrated for one proton appeared at $06.14 \mathrm{ppm}$ and attributed to the methine proton of the pyrazole ring. The ${ }^{13} \mathrm{C}-\mathrm{NMR}$ spectrum of compound 14 showed peaks at $\delta 13.8,14.8$ ppm assigned for $2 \mathrm{CH}_{3}$ groups of the pyrazole ring and at $110.9 \mathrm{ppm}$ assigned for $(\mathrm{CH})$ of the pyrazole ring. Also, the IR spectrum of compound 14 displayed a band at $1670 \mathrm{~cm}^{-1}$ corresponding to $(\mathrm{C}=\mathrm{O})$ group of the pyrimidone ring and a broad band at $3385 \mathrm{~cm}^{-1}, 3288 \mathrm{~cm}^{-1}$ corresponding to the $\mathrm{NH}_{2}$ group. The electron impact mass spectrum of compound 14 showed a peak at $\mathrm{m} / \mathrm{z} 276(100 \%)$ corresponding to $\left(\mathrm{M}^{+}+1\right)$.

Compound 12 is further utilized for the synthesis of $\mathrm{N}^{\prime}$-(3-amino-7-methyl-5oxo-5 $H$-thiazolo[3,2-a]pyrimidin-2-yl)-2-cyano aceto hydrazide (15) and 3 amino-2- (5-amino-3- hydroxy-1H-pyrazolyl) -7-methyl-5H-thiazolo $[3,2-$ a]pyrimidin-5-one (17), respectively (Scheme 5). This is accomplished through the reaction of compound 12 with ethyl cyanocetate in absolute ethanol with subsequent elimination of ethanol molecule to afford compound 15. Structure of compound 15 is confirmed on the basis of elemental analyses and spectral data. The electron impact mass spectrum of compound 15 showed a peak at $\mathrm{m} / \mathrm{z} \quad 279$ $(5 \%)$ corresponding to $\left(\mathrm{M}^{+}+1\right)$. The IR spectrum of compound 15 displayed a band at $2215 \mathrm{~cm}^{-1}$ corresponding to the $(\mathrm{CN})$ group.

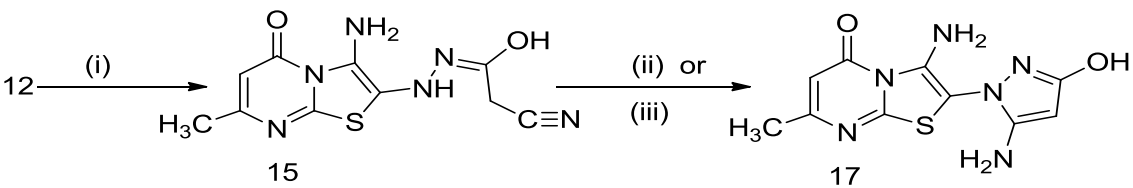

Scheme 5. Synthetic pathways for compounds 15 and 17. Reagents \& conditions: i: Ethyl cyanoacetate/abs. ethanol/reflux (2h); ii: Abs. ethanol/reflux (12h); iii: Sod. ethoxide/abs.ethanol/ reflux (6h).

Egypt. J. Chem. 59, No. 3 (2016) 
The presence of the keto-enol form of compounds 15 and 16 (Scheme 6) is elucidated with the help of spectral data. Thus, the ${ }^{1} \mathrm{H}-\mathrm{NMR}$ spectrum revealed a $\mathrm{D}_{2} \mathrm{O}$ exchangeable singlet integrated for one proton at $03.98 \mathrm{ppm}$ which is attributed to alcoholic $\mathrm{OH}$ group, indicating the presence of the enol form 15 . The IR spectrum displayed bands at $3757 \mathrm{~cm}^{-1}$ corresponding to broad $\mathrm{OH}$ group, which indicates the presence of the enol form 15 and at $1630 \mathrm{~cm}^{-1}$ corresponding to $(\mathrm{C}=\mathrm{O})$ group, which indicates the presence of the keto form 16 .<smiles>Cc1cc(=O)n2c(N)c(NN=C(O)CC#N)sc2n1</smiles>

Scheme 6. The tautomerism in the two forms 15 and 16.

Cyclizing compound 15 either by prolonged heating in absolute ethanol or by heating in ethanolic sodium ethoxide solution, produced compound 17 . Its ${ }^{1} \mathrm{H}-\mathrm{NMR}$ spectrum revealed a singlet signal integrated for one proton at $06.3 \mathrm{ppm}$ attributed to the methine proton of the pyrazole ring. The electron impact mass spectrum of compound 17 showed a peak at $m / z 279(45 \%)$ corresponding to $\left(\mathrm{M}^{+}+1\right)$.

Structure of compound 18 (Scheme 7) was elucidated with the help of spectral data. The ${ }^{1} \mathrm{H}-\mathrm{NMR}$ spectrum of the compound 18 revealed the presence of one triplet and one quartet signals at $\delta 01.14$ and $04.02 \mathrm{ppm}$ attributed to $\mathrm{CH}_{3} \mathrm{CH}_{2}$ of ethyl ester group. This means that the condensation reaction of compound 12 with ethyl acetoacetate in absolute ethanol eliminated a water molecule not an ethanol molecule. The IR spectrum displayed a band at $1740 \mathrm{~cm}^{-1}$ corresponding to $(\mathrm{C}=\mathrm{O})$ of the ethyl ester group and also its electron impact mass spectrum showed a peak at $m / z, 324(4.16 \%)$ corresponding to $\left(\mathbf{M}^{+}+1\right)$.

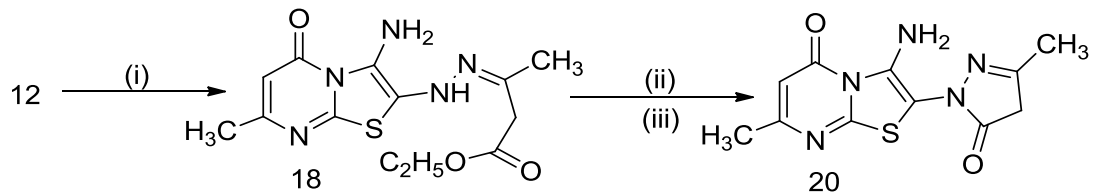

Scheme 7. Synthetic pathways for compounds 18 and 20 . Reagents \& conditions: i: Ethyl acetoacetate/ abs. ethanol/reflux (2h); ii: Sod. ethoxide/abs.ethanol/ reflux (2h); iii:Abs. ethanol/ reflux (6h).

The tautomerism in compounds 18 and 19 (Scheme 8) was confirmed from the ${ }^{1} \mathrm{H}-\mathrm{NMR}$ spectrum which revealed the presence of a singlet signal integrated for two protons at $\delta 01.9 \mathrm{ppm}$ attributed to active methylene in chain, which indicates the presence of the form 18. In addition, a singlet signal integrated for one proton appeared at $\delta 05.9 \mathrm{ppm}$ due to methine proton in the chain, which 
indicates the presence of the form 19 . The ${ }^{13} \mathrm{C}$-NMR spectrum showed signals at $\delta 42.3 \mathrm{ppm}$ corresponding to the active methylene of the form 18 , at $\delta 90.9 \mathrm{ppm}$ corresponding to methine carbon atom of the form 19, at $162.7 \mathrm{ppm}$ due to $(\mathrm{C}=\mathrm{O})$ group of the pyrimidone ring and at $169.4 \mathrm{ppm} 170.5 \mathrm{ppm}$ corresponding to two $(\mathrm{C}=\mathrm{O})$ groups of the ethyl ester group in the two forms 18 and 19.<smiles></smiles>

Scheme 8. The tautomerism in the two forms 18 and 19.

3-Amino-7-methyl-2-(3-methyl-5-oxo-4,5-dihydro-pyrazolyl) -thiazolo[3,2-a] pyrimidin-5-one (20) (Scheme 7) could be produced by cyclization of compound 18 either by heating in absolute ethanol or by heating in ethanolic sodium ethoxide solution. Its ${ }^{1} \mathrm{H}-\mathrm{NMR}$ spectrum revealed the presence of a singlet signal integrated for three protons at $\delta 1.8 \mathrm{ppm}$ attributed to $\mathrm{CH}_{3}$ group in the pyrazolone ring, while its electron impact mass spectrum showed a base peak at $\mathrm{m} / \mathrm{z} 278$ corresponding to $\left(\mathrm{M}^{+}+1\right)$.

The keto-enol type of tautomerism in compound 20 (Scheme 9) is outlined from the ${ }^{1} \mathrm{H}-\mathrm{NMR}$ spectrum which revealed the presence of a singlet signal integrated for two protons at $\delta 02.5 \mathrm{ppm}$ attributed to active methylene in the pyrazolone ring of the form 21 and a singlet signal integrated for one proton at $\delta$ $05.9 \mathrm{ppm}$ attributed to methine proton in the pyrazole ring of the form 20 . The ${ }^{13} \mathrm{C}$-NMR spectrum showed signals at $\delta 42.3 \mathrm{ppm}$ corresponding to $\left(\mathrm{CH}_{2}\right)$ and at $162,166 \mathrm{ppm}$ corresponding to $(2 \mathrm{C}=\mathrm{O})$ groups of the pyrimidone ring and of the form 21. In addition, a signal appeared at $\delta 90 \mathrm{ppm}$ corresponding to $(\mathrm{CH})$ of the pyrimidone ring and at $\delta 91.5 \mathrm{ppm}$ corresponding to $(\mathrm{CH})$ of the pyrazole ring of the form 20. The IR spectrum displayed bands at $3700 \mathrm{~cm}^{-1}$ corresponding to $(\mathrm{OH})$ of the pyrazole ring of the form 20 and at $1637 \mathrm{~cm}^{-1}, 1680 \mathrm{~cm}^{-1}$ corresponding to $(2 \mathrm{C}=\mathrm{O})$ groups of the pyrimidone ring and of the pyrazolone ring of the form 21 .

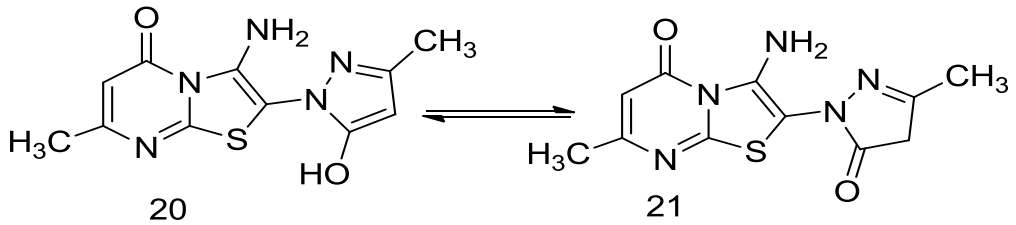

Scheme 9. The tautomerism in compounds 20 and 21.

The synthesis of the Schiff's bases 22(a-d) could be produced by condensing compound 18 with aromatic and heterocyclic aromatic aldehydes, upon heating under reflux in dry pyridine \ piperidine mixture (1:1) or by condensing compound 21 with aromatic and heterocyclic aldehydes under fusion at $140^{\circ} \mathrm{C}$ (Scheme 10).

Egypt. J. Chem. 59, No. 3 (2016) 


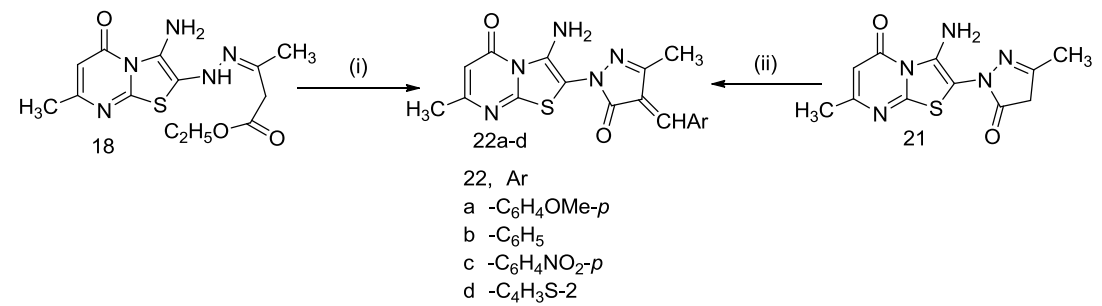

Scheme 10. Synthetic pathways for compounds 22a-d. Reagents \& conditions: i:The appropriate aromatic or heterocyclic aldehydes /dry pyridine /reflux; ii: The appropriate aromatic or heterocyclic aldehydes / fusion at $140^{\circ} \mathrm{C}$.

Structure of compound 22a (Scheme 10) was confirmed on the basis of elemental analyses and spectral data. Its electron impact mass spectrum showed a peak at $m / z, 396(5 \%)$ corresponding to $\left(\mathbf{M}^{+}+1\right)$. The ${ }^{1} \mathrm{H}-\mathrm{NMR}$ spectrum of compound $22 \mathrm{a}$ revealed the absence of the signal attributed to active methylene and the presence of a singlet signal integrated for three protons at $\delta 03.7 \mathrm{ppm}$ which is attributed to the $\mathrm{CH}_{3} \mathrm{O}$ group and a singlet signal integrated for one proton at $\delta 08.8 \mathrm{ppm}$ for the azomethine proton. The IR spectrum of compound 22 a exhibited absorption bands at $1719 \mathrm{~cm}^{-1}$ due to $(C=O)$ group of the pyrazolone ring, $1665 \mathrm{~cm}^{-1}$ due to $(\mathrm{C}=\mathrm{O})$ group of the pyrimidone ring and at $3429,3370 \mathrm{~cm}^{-1}$ due to the $\mathrm{NH}_{2}$ group.

\section{Chemistry}

\section{Experimental}

All melting points are uncorrected and determined on Gallenkamp electric melting point apparatus. The IR spectra were recorded $(\mathrm{KBr})$ on a Perkin-Elmer 1430 spectrometer (National Research Centre). The ${ }^{1} \mathrm{H}-\mathrm{NMR}$ and ${ }^{13} \mathrm{C}-\mathrm{NMR}$ spectra were recorded in $\delta$ ppm scale on Jeol ECA 500 spectrometer, run at 500 $\mathrm{MHz}$ for ${ }^{1} \mathrm{H}-\mathrm{NMR}$ and $125 \mathrm{MHz}$ for ${ }^{13} \mathrm{C}-\mathrm{NMR}$ (National Research Centre) with TMS $\left(\mathrm{SiMe}_{4}\right)$ as internal standard. The coupling constant values are reported in Hz. Mass spectra were recorded on GCMS-QP 1000 EX Shimadzu Japan (Gas Chromatography-Mass spectrometer). Elemental analytical data (in accord with the calculated values) were obtained at the Elemental Analytical Centre at National Research Centre, Egypt. All reactions were followed and the purity of the newly synthesized compounds were assessed by thin layer chromatography (TLC) Merck Alufolien Kieselgel Silica Gel 60 F254 (aluminum sheets 20×20 $\mathrm{cm})$ using $\mathrm{CHCl}_{3} / \mathrm{CH}_{3} \mathrm{OH}(9: 1 \mathrm{v} / \mathrm{v})$ as eluent and detected by UV-absorpion at $254 \mathrm{~nm}$.

Synthesis of 3-amino-2-hydroxy-7-methyl-5H-thiazolo[3,2-a]pyrimidin-5-one (5)

A mixture of 2-bromo cyanoacetamide (10 mmole), ethyl acetoacetate (10 mmole) and thiourea (10 mmole) in ethoxide solution prepared by dissolving sodium metal $(0.79 \mathrm{gm}, 30 \mathrm{mmole})$ in $30 \mathrm{ml}$ of absolute ethanol (dry conditions) was heated under reflux for $5 \mathrm{~h}$. The precipitate separated by pouring the reaction mixture onto $10 \mathrm{ml}$ of ice-water was collected and washed with $10 \mathrm{ml}$ ethanol 
and dried then crystallized from DMF: $\mathrm{H}_{2} \mathrm{O}(1: 1)$. White powder, yield, 85\%, m.p. $228-230^{\circ} \mathrm{C}$. IR $(\mathrm{KBr}) \mathrm{cm}^{-1}: 3766 \mathrm{~cm}^{-1}(\mathrm{OH}) ; 3385,3288 \mathrm{~cm}^{-1}\left(\mathrm{NH}_{2}\right) ; 1716,1675$ $\mathrm{cm}^{-1}(2 \mathrm{C}=\mathrm{O})$ groups. ${ }^{1} \mathrm{H}-\mathrm{NMR}$ (DMSO- $\left.d_{6}, 500 \mathrm{MHz}\right) \delta(\mathrm{ppm}): 01.9 \mathrm{ppm}(\mathrm{s}, 3 \mathrm{H}$, $\left.\mathrm{CH}_{3}\right) ; 03.2 \mathrm{ppm}(\mathrm{s}, 1 \mathrm{H}, \mathrm{CH}$ of the new thiazole ring); $05.3 \mathrm{ppm}(\mathrm{s}, 1 \mathrm{H}, \mathrm{CH}$ of pyrimidine ring); $07.3 \mathrm{ppm}$ (br.s, $2 \mathrm{H}, \mathrm{NH}_{2}, \mathrm{D}_{2} \mathrm{O}$ exchangeable); $10.8 \mathrm{ppm}$ (br.s, $1 \mathrm{H}, \mathrm{OH}, \mathrm{D}_{2} \mathrm{O}$ exchangeable). ${ }^{13} \mathrm{C}-\mathrm{NMR}$ (DMSO- $\left.d_{6}, 125 \mathrm{MHz}\right) \delta(\mathrm{ppm}): \delta$ 18.6 $\left(\mathrm{CH}_{3}\right), \quad 42(\mathrm{CH}), \quad 99.2\left(\mathrm{C}_{2}\right), \quad 104.1\left(\mathrm{C}_{5}\right), \quad 151.9\left(\mathrm{C}_{3}\right), \quad 153.6\left(\mathrm{C}_{6}\right), \quad 153.7\left(\mathrm{C}_{8}\right)$, 164.7(tertary amidic $(\mathrm{C}=\mathrm{O})$ group in the pyrimidone ring $), 171((\mathrm{C}=\mathrm{O})$ group in thiazolone ring). MS. (m/z, \%):198 $\left(\mathrm{M}^{+}+1,100\right) ; 166(83) ; 96(55)$. Anal. Calcd for $\mathrm{C}_{7} \mathrm{H}_{7} \mathrm{~N}_{3} \mathrm{O}_{2} \mathrm{~S}$ (197): $\mathrm{C}, 42.63 ; \mathrm{H}, 03.58 ; \mathrm{N}, 21.31 ; \mathrm{S}, 16.26$ (\%). Found: $\mathrm{C}$, $42.73 ; \mathrm{H}, 03.59 ; \mathrm{N}, 21.33 ; \mathrm{S}, 16.25(\%)$.

Synthesis of 3-amino-2-hydrazinyl-7-methyl-5H-thiazolo[3,2-a]pyrimidin-5-one (12)

A mixture of compound 5 (01.97 gm, 10 mmole) and hydrazine hydrate $99 \%$ $(6 \mathrm{ml})$ in catalytic amount of acetic acid $(1 \mathrm{ml})$ were refluxed in ethanol $(30 \mathrm{ml})$ for $5 \mathrm{~h}$. The reaction mixture was allowed to cool to room temperature. The solid was collected by filtration then crystallized from $60 \%$ ethanol.

Yellow powder, yield, $40 \%$, m.p. $290-292^{\circ} \mathrm{C}$. IR $(\mathrm{KBr}) \mathrm{cm}^{-1}: 3426-3237 \mathrm{~cm}^{-1}$ $\left(2 \mathrm{NH}_{2}\right) ; 3109 \mathrm{~cm}^{-1}(\mathrm{NH}) ; 2924 \mathrm{~cm}^{-1}$ (CH-aliphatic); $1675 \mathrm{~cm}^{-1}$ (C=O). ${ }^{1} \mathrm{H}-\mathrm{NMR}$ (DMSO- $\left.d_{6}, 500 \mathrm{MHz}\right) \delta(\mathrm{ppm}): 01.9 \mathrm{ppm}\left(\mathrm{s}, 3 \mathrm{H}, \mathrm{CH}_{3}\right), 02.0 \mathrm{ppm}(\mathrm{s}, 1 \mathrm{H}, \mathrm{CH}$ of the thiazole ring), $04.45 \mathrm{ppm}$ (br.s, $2 \mathrm{H}, \mathrm{NH}_{2}$, disappeared by $\mathrm{D}_{2} \mathrm{O}$ exchange), $05.3 \mathrm{ppm}\left(\mathrm{s}, 1 \mathrm{H}, \mathrm{CH}\right.$ of the pyrimidone ring), $08.7 \mathrm{ppm}$ (br. s, $3 \mathrm{H},\left(\mathrm{NH}+\mathrm{NH}_{2}\right)$, disappeared by $\mathrm{D}_{2} \mathrm{O}$ exchange). MS. (m/z, \%): $212\left(\mathrm{M}^{+}+1,5\right) ; 166(100) ; 96(65)$. Anal. Calcd for $\mathrm{C}_{7} \mathrm{H}_{9} \mathrm{~N}_{5} \mathrm{OS}$ (211): C, 39.80; H, 04.29; N, 33.15; S, $15.18(\%)$. Found: C, 39.71; H, 04.30; N, 33.17; S, 15.19 (\%).

Synthesis of 3-amino-2-(3,5-dimethyl-1H-pyrazolyl)-7-methyl-5H-thiazolo[3,2a] pyrimidin-5-one (14)

A mixture of compound $12(02.11 \mathrm{gm}, 10 \mathrm{mmole})$ and pentan-2,4-dione (10 mmole) was heated under reflux in dry dioxane $(30 \mathrm{ml})$ for $5 \mathrm{~h}$. The reaction mixture was allowed to cool to room temperature and the solid precipitate was filtered off, washed thoroughly with ethanol and dried then crystallized from dioxane.

Yellow powder, yield, 55\%, m.p. $132-134^{\circ} \mathrm{C}$. IR $(\mathrm{KBr}) \mathrm{cm}^{-1}: 3440 \mathrm{~cm}^{-1}$, $32700 \mathrm{~cm}^{-1} \mathrm{NH}_{2}$ group and $1670 \mathrm{~cm}^{-1}(\mathrm{C}=\mathrm{O})$ group. ${ }^{1} \mathrm{H}-\mathrm{NMR}$ (DMSO- $d_{6}, 500$ $\mathrm{MHz}) \delta(\mathrm{ppm}): 02.15 \mathrm{ppm}\left(\mathrm{s}, 3 \mathrm{H}, \mathrm{CH}_{3}\right.$ of the pyrimidine ring); $02.19 \mathrm{ppm}(\mathrm{s}, 3 \mathrm{H}$, $\mathrm{CH}_{3}$ of pyrazole ring); $02.50 \mathrm{ppm}\left(\mathrm{s}, 3 \mathrm{H}, \mathrm{CH}_{3}\right.$ of the new pyrazole ring); 05.33 ppm (s, $1 \mathrm{H}, \mathrm{CH}$ of pyrimidine ring); $06.14 \mathrm{ppm}(\mathrm{s}, 1 \mathrm{H}, \mathrm{CH}$ of the new pyrazole ring); $12.12 \mathrm{ppm}$ (br.s, $2 \mathrm{H}, \mathrm{NH}_{2}$, disappeared by $\mathrm{D}_{2} \mathrm{O}$ exchange) ${ }^{13} \mathrm{C}-\mathrm{NMR}$ (DMSO- $\left.d_{6}, 125 \mathrm{MHz}\right) \delta(\mathrm{ppm}): \delta 13.8 \mathrm{ppm}$ and $14.8 \mathrm{ppm}$ (two carbon atoms of $2 \mathrm{CH}_{3}$ groups of the new pyrazole ring), $23.8\left(\mathrm{CH}_{3}\right.$ group of the pyrimidone ring), $107.4(\mathrm{CH}$ of the pyrimidone ring), 110.9 ( $\mathrm{CH}$ of the new pyrazole ring) and at $164.7((\mathrm{C}=\mathrm{O})$ group in the pyrimidone ring $)$. MS. $(\mathrm{m} / \mathrm{z}, \%): 276\left(\mathrm{M}^{+}+1,100\right)$; 166 (80); 96(60). Anal. Calcd for $\mathrm{C}_{12} \mathrm{H}_{13} \mathrm{~N}_{5} \mathrm{OS}$ (275): C, 52.35; H, 4.76; N, 25.44; S, 11.65 (\%). Found: C, 52.25; H, 04.75; N, 25.43; S, 11.66 (\%).

Egypt. J. Chem. 59, No. 3 (2016) 
Synthesis of N'-(3-amino-7-methyl-5-oxo-5H-thiazolo[3,2-a]pyrimidin-2-yl)-2cyanoacetohydrazide (15)

A mixture of compound $12(02.11 \mathrm{gm}, 10 \mathrm{mmole})$ and ethyl cyanoacetate $(01.33 \mathrm{gm}, 10 \mathrm{mmole})$ was heated under reflux in absolute ethanol $(30 \mathrm{ml})$ for 2 h. The reaction mixture was allowed to cool to room temperature and the solid precipitate was filtered off, washed thoroughly with ethanol and dried then crystallized from dioxane.

Yellow powder, yield, 55\%, m.p. $243-245^{\circ} \mathrm{C}$. IR $(\mathrm{KBr}) \mathrm{cm}^{-1}: 3750 \mathrm{~cm}^{-1}$ $(\mathrm{OH}) ; 3432,3337 \mathrm{~cm}^{-1}\left(\mathrm{NH}_{2}\right) ; 3237,3154 \mathrm{~cm}^{-1}(2 \mathrm{NH}) ; 2923 \mathrm{~cm}^{-1}(\mathrm{CH}-$ aliphatic); $2215 \mathrm{~cm}^{-1}(\mathrm{CN}) ; 1640,1630 \mathrm{~cm}^{-1}(2 \mathrm{C}=\mathrm{O}) .{ }^{1} \mathrm{H}$ NMR (DMSO-d 6 , 500 MHz) $\delta$ (ppm): 01.9 ppm (s, 3H, $\left.\mathrm{CH}_{3}\right) ; 03.1 \mathrm{ppm}\left(\mathrm{s}, 2 \mathrm{H}, \mathrm{CH}_{2}\right) ; 04.5 \mathrm{ppm}($ br. s, $1 \mathrm{H}$, ethanolic $(\mathrm{OH})$, disappeared by $\mathrm{D}_{2} \mathrm{O}$ exchange $) ; 05.3 \mathrm{ppm}(\mathrm{s}, 1 \mathrm{H}, \mathrm{CH}$ of the pyrimidone ring); 08.7 ppm (br.s, $2 \mathrm{H}, \mathrm{NH}_{2}$, disappeared by $\mathrm{D}_{2} \mathrm{O}$ exchange); 09.8 ppm ( br.s, $2 \mathrm{H}, 2 \mathrm{NH}$, disappeared by $\mathrm{D}_{2} \mathrm{O}$ exchange). $\mathrm{MS}$. (m/z, \%): $279\left(\mathrm{M}^{+}+1\right.$, 5); 140 (50); 69 (100). Anal. Calcd for $\mathrm{C}_{10} \mathrm{H}_{10} \mathrm{~N}_{6} \mathrm{O}_{2} \mathrm{~S}$ (278): C, 43.16; H, 03.62; N, 30.20; S, $11.52(\%)$. Found: C, 43.07; H, 03.61; N, 30.29; S, $11.51(\%)$.

Synthesis of 3-amino-2-(5-amino-3-hydroxy-1H-pyrazolyl)-7-methyl-5H-thiazolo [3,2-a] pyrimidin-5-one (17)

$\operatorname{Method}(A)$

A solution of compound $15(02.78 \mathrm{gm}, 10 \mathrm{mmole})$ in $30 \mathrm{ml}$ absolute ethanol, (dry conditions), was heated under reflux for $6 \mathrm{~h}$. The reaction mixture was allowed to cool to room temperature, then poured onto ice-water $(30 \mathrm{ml})$. The precipitated solid was filtered off and dried then crystallized from dioxane to produce the pure compound 17 in $65 \%$ yield, m.p. $\left(268-270^{\circ} \mathrm{C}\right)$.

Method (B)

A solution of compound $15(02.78 \mathrm{gm}, 10 \mathrm{mmole})$ in sodium ethoxide solution (prepared by dissolving sodium metal $(0.23 \mathrm{gm}, 10 \mathrm{mmol})$ in $30 \mathrm{ml}$ of absolute ethanol), (dry conditions), was heated under reflux for $2 \mathrm{~h}$. The reaction mixture was allowed to cool to room temperature, poured onto ice-water $(30 \mathrm{ml})$, then neutralized with conc. $\mathrm{HCl}(1 \mathrm{ml})$, whereby a solid was precipitated, filtered off and dried to produce a compound identical in all aspects with 17 (m.p., mixed m.p. and comparative IR spectra) in $50 \%$ yield.

$\operatorname{Method}(C)$

A mixture of compound $12(02.11 \mathrm{gm}, 10 \mathrm{mmole})$ and ethyl cyanoacetate $(01.33 \mathrm{gm}, 10 \mathrm{mmole})$ was heated under reflux in absolute ethanol $(30 \mathrm{ml})$, (dry conditions), for $12 \mathrm{~h}$. The reaction mixture was poured onto ice-water $(10 \mathrm{ml})$. The solid precipitate was filtered off, washed thoroughly with ethanol and dried to produce compound 17 in $60 \%$ yield. The obtained compound has the same data as that obtained from methods (A) and (B).

Red powder, m.p. $268-270^{\circ} \mathrm{C}$. IR $(\mathrm{KBr}) \mathrm{cm}^{-1}: 3500 \mathrm{~cm}^{-1}(\mathrm{OH}) ; 3409,3331$, $3217,3170 \mathrm{~cm}^{-1}\left(2 \mathrm{NH}_{2}\right)$ and $1693 \mathrm{~cm}^{-1}(\mathrm{C}=\mathrm{O}) .{ }^{1} \mathrm{H}-\mathrm{NMR}$ (DMSO- $\left.d_{6}, 500 \mathrm{MHz}\right)$ $\delta$ (ppm): $2.2 \mathrm{ppm}$ (s, 3H, $\mathrm{CH}_{3}$ of pyrimidine ring); $4.2 \mathrm{ppm}$ (br.s, $2 \mathrm{H}, \mathrm{NH}_{2}$ of 
new pyrazole ring, disappeared by $\mathrm{D}_{2} \mathrm{O}$ exchange); $5.6 \mathrm{ppm}(\mathrm{s}, 1 \mathrm{H}, \mathrm{CH}$ of the pyrimidine ring); $6.3 \mathrm{ppm}$ (s, $1 \mathrm{H}, \mathrm{CH}$ of the new pyrazole ring); $8.3 \mathrm{ppm}$ (br.s, $2 \mathrm{H}, \mathrm{NH}_{2}$ of the new thiazole ring, disappeared by $\mathrm{D}_{2} \mathrm{O}$ exchange); $11.31 \mathrm{ppm}$ (br.s, $1 \mathrm{H}, \mathrm{OH}$, disappeared by $\mathrm{D}_{2} \mathrm{O}$ exchange). MS. $(\mathrm{m} / \mathrm{z}, \%): 279\left(\mathrm{M}^{+}+1,45\right)$; 182 (5); 164 (25); 56 (100). Anal. Calcd for $\mathrm{C}_{10} \mathrm{H}_{10} \mathrm{~N}_{6} \mathrm{O}_{2} \mathrm{~S}$ (278): C, 43.16; $\mathrm{H}$, 03.62; N, 30.20; S, 11.52 (\%). Found: C, 43.20; H, 03.63; N, 30.25; S, 11.51 (\%).

Synthesis of ethyl 3-(2-(3-amino-7-methyl-5-oxo-5H-thiazolo[3,2-a] pyrimidin-2yl) hydrazono)butanoate (18)

A mixture of compound $12(02.11 \mathrm{gm}, 10 \mathrm{mmole})$ and ethyl acetoacetate $(01.30 \mathrm{gm}, 10 \mathrm{mmole})$ was heated under reflux in absolute ethanol $(30 \mathrm{ml})$ for $2 \mathrm{~h}$. The reaction mixture was allowed to cool to room temperature and the solid precipitate was filtered off, washed thoroughly with ethanol, dried and crystallized from ethanol to produce the pure compound 18.

Yello powder, yield, $87 \%$, m.p. $134-136^{\circ} \mathrm{C}$. IR $(\mathrm{KBr}) \mathrm{cm}^{-1}: 3442,3335 \mathrm{~cm}^{-1}$ $\left(\mathrm{NH}_{2}\right) ; 3161,3105 \mathrm{~cm}^{-1}(2 \mathrm{NH}) ; 2923 \mathrm{~cm}^{-1}$ (CH-aliphatic); 1739, $1663 \mathrm{~cm}^{-1}$ $(2 \mathrm{C}=\mathrm{O}){ }^{1} \mathrm{H}-\mathrm{NMR}$ (DMSO- $\left.d_{6}, 500 \mathrm{MHz}\right) \delta(\mathrm{ppm}): 01.14 \mathrm{ppm}\left(\mathrm{t}, 3 \mathrm{H}, J=8 \mathrm{~Hz}, \mathrm{CH}_{3}\right.$ of ester group); 01.91, $01.96 \mathrm{ppm}\left(\mathrm{s}, 6 \mathrm{H}, 2 \mathrm{CH}_{3}\right) ; 02.0,2.1 \mathrm{ppm}\left(\mathrm{s}, 6 \mathrm{H}, 2 \mathrm{CH}_{3}\right.$ of pyrimidone ring); $04.02 \mathrm{ppm}$ (q, $2 \mathrm{H}, J=8 \mathrm{~Hz}, \mathrm{CH}_{2}$ of ester group); $04.2 \mathrm{ppm}$ (br.s, $4 \mathrm{H}, 2 \mathrm{NH}_{2}$, disappeared by $\mathrm{D}_{2} \mathrm{O}$ exchange) $05.2,05.3 \mathrm{ppm}$ (s., $2 \mathrm{H}, 2 \mathrm{CH}$ in pyrimidone ring); $05.9 \mathrm{ppm}$ (s., $1 \mathrm{H}, \mathrm{CH}$ of the form 19); $10.07 \mathrm{ppm}$ (br. s., $2 \mathrm{H}$, $(2 \mathrm{NH})$, disappeared by $\mathrm{D}_{2} \mathrm{O}$ exchange). ${ }^{13} \mathrm{C}-\mathrm{NMR}$ (DMSO- $d_{6}, 125 \mathrm{MHz}$ ): $\delta$ (ppm): 13.1, $14.5\left(2 \mathrm{CH}_{3}\right.$ of ethyl groups); 17.1, $21.8\left(2 \mathrm{CH}_{3}\right.$ groups $) ; 23.4,23.6$ $\left(2 \mathrm{CH}_{3}\right.$ groups in the pyrimidone ring); $42.3\left(\mathrm{CH}_{2}\right.$ of the form 18$) ; 60.9\left(\mathrm{CH}_{2}\right.$ of ethyl group); $90.8((\mathrm{CH})$ of the form 19$) ; 107.9((\mathrm{CH})$ in the pyrimidone ring $)$; $151.2\left(\mathrm{C}_{3}\right) ; 152.5\left(\mathrm{C}_{6}\right) ; 153.9\left(\mathrm{C}_{8}\right) ; 162.7((\mathrm{C}=\mathrm{O})$ group in the pyrimidone ring $)$; $169.3,170.4(2(\mathrm{C}=\mathrm{O})$ of ester group in the forms 18 and 19$)$. MS. $(\mathrm{m} / \mathrm{z}, \%)$ : 324( $\left.\mathrm{M}^{+}+1,4.16\right) ; 253(85) ; 166$ (100). Anal. Calcd for $\mathrm{C}_{13} \mathrm{H}_{17} \mathrm{~N}_{5} \mathrm{O}_{3} \mathrm{~S}$ (323): C, 48.28; H, 05.30; N, 21.66; S, 09.92 (\%). Found: C, 48.38; H, 05.29; N, 21.71; S, $09.93(\%)$.

Synthesis of 3-amino-7- methyl-2- (3-methyl-5-oxo-4,5- dihydro-1H-pyrazolyl) 5H-thiazolo [3,2-a] pyrimidin-5-one (20)

$\operatorname{Method}(A)$

A solution of compound $18(03.23 \mathrm{gm}, 10 \mathrm{mmole})$ in $30 \mathrm{ml}$ of absolute ethanol (dry conditions), was heated under reflux for $6 \mathrm{~h}$. The reaction mixture was allowed to cool to room temperature, poured onto ice-water $(10 \mathrm{ml})$, whereby a solid was precipitated, which was filtered off and crystallized from ethanol to produce the pure compound 20 in $75 \%$ yield, m.p. $\left(268-270^{\circ} \mathrm{C}\right)$.

\section{Method (B)}

A solution of compound $18(03.23 \mathrm{gm}, 10 \mathrm{mmole})$ in sodium ethoxide solution (prepared by dissolving sodium metal $(00.23 \mathrm{gm}, 10 \mathrm{mmol})$ in $30 \mathrm{ml}$ of absolute ethanol) (dry conditions), was heated under reflux for $2 \mathrm{~h}$ till the starting material disappeared (TLC). The reaction mixture was allowed to cool to room temperature, poured onto ice-water $(30 \mathrm{ml})$, and neutralized with conc $\mathrm{HCl}(1 \mathrm{ml})$, Egypt. J. Chem. 59, No. 3 (2016) 
whereby a solid was precipitated, filtered off and dried to produce compound $\mathbf{2 0}$ in $68 \%$ yield.

\section{$\operatorname{Method}(C)$}

A mixture of compound $12(02.11 \mathrm{gm}, 10 \mathrm{mmole})$ and ethyl acetoacetate $(01.30 \mathrm{gm}, 10 \mathrm{mmole})$ was heated under reflux in absolute ethanol $(30 \mathrm{ml})$ (dry conditions) for $10 \mathrm{~h}$ till the starting material disappeared (TLC). The reaction mixture was allowed to cool to room temperature then poured onto ice-water $(10 \mathrm{ml})$. The solid precipitate was filtered off, washed thoroughly with ethanol and dried to produce compound 20 in $78 \%$ yield. This compound has the same data as that obtained from methods (A) and (B). Orange powder, m.p. $268^{\circ}$ $270^{\circ} \mathrm{C}$. IR $(\mathrm{KBr}) \mathrm{cm}^{-1}: 3700 \mathrm{~cm}^{-1}(\mathrm{OH}) ; 3428,3350 \mathrm{~cm}^{-1}\left(\mathrm{NH}_{2}\right) ; 3100 \mathrm{~cm}^{-1}(\mathrm{CH}-$ aromatic); $2924 \mathrm{~cm}^{-1}$ (CH-aliphatic); $1680 \mathrm{~cm}^{-1}, 1637 \mathrm{~cm}^{-1}(2 \mathrm{C}=\mathrm{O}) .{ }^{1} \mathrm{H}-\mathrm{NMR}$ $\left(\mathrm{DMSO}-d_{6}, 500 \mathrm{MHz}\right) \delta(\mathrm{ppm}): 01.8 \mathrm{ppm}\left(\mathrm{s}, 3 \mathrm{H}, \mathrm{CH}_{3}\right.$ of the pyrazolone ring ); $02.18 \mathrm{ppm}$ (s, $3 \mathrm{H}, \mathrm{CH}_{3}$ of pyrimidone ring ); $02.5 \mathrm{ppm}\left(\mathrm{s}, 1 \mathrm{H}, \mathrm{CH}_{2}\right.$ in the newly pyrazole ring of the form 21); $5.3 \mathrm{ppm}(\mathrm{s}, 1 \mathrm{H}, \mathrm{CH}$ of pyrimidone ring); $5.9 \mathrm{ppm}$ (s, $1 \mathrm{H}, \mathrm{CH}$ of the pyrazole ring of the form 20$) ; 12.5 \mathrm{ppm}$ (br. s, $3 \mathrm{H},\left(\mathrm{NH}_{2}+\mathrm{OH}\right)$ disappeared by $\mathrm{D}_{2} \mathrm{O}$ exchange). ${ }^{13} \mathrm{C}-\mathrm{NMR}$ (DMSO- $\left.d_{6}, 125 \mathrm{MHz}\right) \delta(\mathrm{ppm})$ : $12.8\left(\mathrm{CH}_{3}\right.$ group in the pyrazole ring); $23.5\left(\mathrm{CH}_{3}\right.$ group in pyrimidone ring); $42.3\left(\mathrm{CH}_{2}\right.$ of the pyrazolone ring of the form 21$) ; 90(\mathrm{CH}$ of pyrimidone ring ); $91.4(\mathrm{CH})$ of the pyrazole ring of the form $20 ; 98.6\left(\mathrm{C}_{5}^{\prime}\right.$ of the pyrazole ring in the form 20$) ; 107.9\left(\mathrm{C}_{5}\right) ; 147.7\left(\mathrm{C}_{2}\right) ; 148.1\left(\mathrm{C}_{3}\right) ; 153.9\left(\mathrm{C}_{6}\right) ; 158.92\left(\mathrm{C}_{8}\right)$; $162.1((\mathrm{C}=\mathrm{O})$ group in the pyrimidone ring $) ; 166.1((\mathrm{C}=\mathrm{O})$ group in the newly pyrazolone ring). MS. (m/z, \%): $278\left(\mathrm{M}^{+}+1,100\right) ; 166$ (25); 96 (11). Anal. Calcd for $\mathrm{C}_{11} \mathrm{H}_{11} \mathrm{~N}_{5} \mathrm{O}_{2} \mathrm{~S}$ (277): C, 47.64; H, 04.00; N, 25.26; S, 11.56 (\%). Found: C, 47.54; H, 04.01; N, 25.21; S, $11.58(\%)$.

\section{Preparation of compounds 22( $a-d)$}

General procedure $(a)$

A mixture of compound $18(03.23 \mathrm{gm}, 10 \mathrm{mmole})$ and 10 mmole of the appropriate aromatic or heterocyclic aldehyde in $15 \mathrm{ml}$ of dry pyridinelpiperidine mixture (1:1) was heated under reflux for $5 \mathrm{~h}$. The reaction mixture was allowed to cool to room temperature, poured onto water $(10 \mathrm{ml})$ neutralized with $(1 \mathrm{ml})$ of $\mathrm{HCl}$ $(36 \%)$, whereby a solid was precipitated, filtered off and crystallized from the proper solvent, to produce the pure derivatives $22(\mathrm{a}-\mathrm{d})$.

\section{General Procedure (B)}

A mixture of compound $21(02.77 \mathrm{gm}, 10 \mathrm{mmole})$ and 10 mmole of the appropriate aromatic or heterocyclic aldehyde was heated for $3 \mathrm{~h}$ at $140^{\circ} \mathrm{C}$. The deposited precipitate was crystallized from the proper solvent to produce the pure free derivatives $22(\mathrm{a}-\mathrm{d})$.

3-Amino-2- (4-(4-methoxybenzylidene) -3-methyl-5-oxo-4,5- dihydro-1Hpyrazolyl)-7-methyl-5H- thiazolo [3,2 a] pyrimidin-5-one (22a)

Dark orange powder, crystallized from ethanol, yield $75 \%$, m.p. $228-230^{\circ} \mathrm{C}$; IR (KBr) cm $\left.\mathrm{cm}^{-1}: 3429,3370 \mathrm{~cm}^{-1}\left(\mathrm{NH}_{2}\right)\right) ; 3011 \mathrm{~cm}^{-1}$ ( $\mathrm{CH}$-aromatic); $2929 \mathrm{~cm}^{-1}$ 
$\mathrm{CH}$-aliphatic) and 1716, $1662 \mathrm{~cm}^{-1}(2 \mathrm{C}=\mathrm{O}) .{ }^{1} \mathrm{H}-\mathrm{NMR}\left(\mathrm{DMSO}-d_{6}, 500 \mathrm{MHz}\right) \delta$ (ppm): $01.89 \mathrm{ppm}\left(\mathrm{s}, 3 \mathrm{H}, \mathrm{CH}_{3}\right.$ of pyrazolone ring ); $01.97 \mathrm{ppm}\left(\mathrm{s}, 3 \mathrm{H}, \mathrm{CH}_{3}\right.$ of pyrimidone ring $) ; 03.78 \mathrm{ppm}\left(\mathrm{s}, 3 \mathrm{H}, \mathrm{CH}_{3} \mathrm{O}\right) ; 05.27 \mathrm{ppm}(\mathrm{s}, 1 \mathrm{H},=\mathrm{CH}$ of pyrimidone ring); $07.01 \mathrm{ppm}(\mathrm{d}, 2 \mathrm{H}, J=9 \mathrm{~Hz}$, Aromatic protons ); $07.76 \mathrm{ppm}$ (d, $2 \mathrm{H}, J=9 \mathrm{~Hz}$, Aromatic protons); $08.60 \mathrm{ppm}$ ((s, 1H, benzylic proton); 10.79 ppm (br. s, $2 \mathrm{H}, \mathrm{NH}_{2}$, disappeared by $\mathrm{D}_{2} \mathrm{O}$ exchange). MS. (m/z, \%): $396\left(\mathrm{M}^{+}+1\right.$, 5); 277 (100); 166 (11). Anal. Calcd for $\mathrm{C}_{19} \mathrm{H}_{17} \mathrm{~N}_{5} \mathrm{O}_{3} \mathrm{~S}$ (395): C, 57.71; H, 04.33; N, 17.71; S, $08.11(\%)$. Found: C, 57.81; H, 04.32; N, 17.67; S, $08.13(\%)$.

3-Amino-2-(4-benzylidene -3-methyl -5-oxo-4,5-dihydro- 1H-pyrazolyl)-7methyl-5H-thiazolo [3,2-a]pyrimidin-5-one (22b)

Red powder, crystallized from dioxane, yield $69 \%$, m.p. $220^{\circ} \mathrm{C}$; IR $(\mathrm{KBr})$ $\mathrm{cm}^{-1}$ : 3428, $3373\left(\mathrm{NH}_{2}\right) ; 3021 \mathrm{~cm}^{-1}$ (CH-aromatic); $2930 \mathrm{~cm}^{-1}$ (CH-aliphatic) and $1715,1665 \mathrm{~cm}^{-1}(2 \mathrm{C}=\mathrm{O}) .{ }^{1} \mathrm{H}-\mathrm{NMR}$ (DMSO- $\left.d_{6}, 500 \mathrm{MHz}\right) \delta(\mathrm{ppm}): 01.88$ ppm (s, $3 \mathrm{H}, \mathrm{CH}_{3}$ of pyrazolone ring ); $02.19 \mathrm{ppm}\left(\mathrm{s}, 3 \mathrm{H}, \mathrm{CH}_{3}\right.$ of pyrimidone ring); $05.28 \mathrm{ppm}(\mathrm{s}, 1 \mathrm{H},=\mathrm{CH}$ of pyrimidone ring $) ; 07.17-07.51 \mathrm{ppm}(\mathrm{m}, 5 \mathrm{H}$, aromatic protons); $08.60 \mathrm{ppm}(\mathrm{s}, 1 \mathrm{H},=\mathrm{CH}$ of benzylic proton); $09.79 \mathrm{ppm}$ (br. s, $2 \mathrm{H}, \mathrm{NH}_{2}$, disappeared by $\mathrm{D}_{2} \mathrm{O}$ exchange). MS. $(\mathrm{m} / \mathrm{z}, \%): 366\left(\mathrm{M}^{+}+1,20\right) ; 277$ (100); 166 (13). Anal. Calcd for $\mathrm{C}_{18} \mathrm{H}_{15} \mathrm{~N}_{5} \mathrm{O}_{2} \mathrm{~S}$ (365): C, 59.16; H, 04.14; N, 19.17; S, 08.78 (\%). Found: C, 59.25; H, 04.12; N, 19.19; S, 08.77 (\%).

3-Amino-7-methyl-2- (3-methyl-4- (4-nitrobenzylidene) -5-oxo-4,5- dihydro1H-pyrazolyl) -5H-thiazolo [3,2-a]pyrimidin-5-one (22c)

Brown powder, crystallized from DMF: $\mathrm{H}_{2} \mathrm{O}(1: 1)$, yield $63 \%$, m.p. $>300^{\circ} \mathrm{C}$; IR (KBr) cm $\mathrm{cm}^{-1}: 3419,3299 \mathrm{~cm}^{-1}\left(\mathrm{NH}_{2}\right) ; 3017 \mathrm{~cm}^{-1}$ ( CH-aromatic); $2929 \mathrm{~cm}^{-1}$ (CH-aliphatic) and 1716, $1663 \mathrm{~cm}^{-1}(2 \mathrm{C}=\mathrm{O}) .{ }^{1} \mathrm{H}-\mathrm{NMR}$ (DMSO- $\left.d_{6}, 500 \mathrm{MHz}\right) \delta$ (ppm): $01.89 \mathrm{ppm}\left(\mathrm{s}, 3 \mathrm{H}, \mathrm{CH}_{3}\right.$ of pyrazolone ring ); $01.97 \mathrm{ppm}\left(\mathrm{s}, 3 \mathrm{H}, \mathrm{CH}_{3}\right.$ of pyrimidone ring ); $05.28 \mathrm{ppm}(\mathrm{s}, 1 \mathrm{H},=\mathrm{CH}$ of pyrimidone ring); $08.11 \mathrm{ppm}(\mathrm{d}, 2$ $\mathrm{H}, J=9 \mathrm{~Hz}$, Aromatic protons ); $08.34 \mathrm{ppm}(\mathrm{d}, 2 \mathrm{H}, J=9 \mathrm{~Hz}$, Aromatic protons); $8.85 \mathrm{ppm}\left(\mathrm{s}, 1 \mathrm{H},=\mathrm{CH}\right.$ of benzylic proton); $10.48 \mathrm{ppm}$ (br. s, $2 \mathrm{H}, \mathrm{NH}_{2}$, disappeared by $\mathrm{D}_{2} \mathrm{O}$ exchange). MS. (m/z, \%): $411\left(\mathrm{M}^{+}+1,7\right) ; 277(100) ; 166$ (15). Anal. Calcd for $\mathrm{C}_{18} \mathrm{H}_{14} \mathrm{~N}_{6} \mathrm{O}_{4} \mathrm{~S}$ (410): C, 52.68; H, 03.44; N, 20.48; S, 07.81 (\%) Found: C, 52.79; H, 03.43; N, 20.53; S, 07.82 (\%).

3-Amino-7-methyl-2-(3-methyl-5-oxo-4-thiophen-2-yl methylene-4,5-dihydro1H-pyrazolyl)-5H-thiazolo[3,2-a]pyrimidin-5-one (22d)

Dark brown powder, crystallized from dioxane, yield $68 \%$, m.p. 224-226 ${ }^{\circ}$; IR (KBr) cm $\mathrm{cm}^{-1}: 3450,3278 \mathrm{~cm}^{-1}\left(\mathrm{NH}_{2}\right) ; 3015 \mathrm{~cm}^{-1}$ (CH-aromatic); $2924 \mathrm{~cm}^{-1}$ (CH-aliphatic) and 1717, $1668 \mathrm{~cm}^{-1}(2 \mathrm{C}=\mathrm{O}) .{ }^{1} \mathrm{H}-\mathrm{NMR}$ (DMSO-d $\left.6,500 \mathrm{MHz}\right) \delta$ (ppm): $01.61 \mathrm{ppm}\left(\mathrm{s}, 3 \mathrm{H}, \mathrm{CH}_{3}\right.$ of pyrazolone ring ); $01.97 \mathrm{ppm}\left(\mathrm{s}, 3 \mathrm{H}, \mathrm{CH}_{3}\right.$ of pyrimidone ring $) ; 05.27 \mathrm{ppm}(\mathrm{s}, 1 \mathrm{H},=\mathrm{CH}$ of pyrimidone ring); $07.18 \mathrm{ppm}(\mathrm{m}$, $1 \mathrm{H}$, thienyl- $\left.\mathrm{C}_{4}-\mathrm{H}\right) ; 07.60 \mathrm{ppm}\left(\mathrm{d}, 1 \mathrm{H}, J=5 \mathrm{~Hz}\right.$, thienyl- $\left.\mathrm{C}_{3}-\mathrm{H}\right), 07.77 \mathrm{ppm}(\mathrm{m}, 1 \mathrm{H}$, thienyl- $\left.\mathrm{C}_{5}-\mathrm{H}\right), 8.83$ ppm (s, $1 \mathrm{H},=\mathrm{CH}$-thienyl proton), 11.07 ppm (br. s, $2 \mathrm{H}$, $\mathrm{NH}_{2}$, disappeared by $\mathrm{D}_{2} \mathrm{O}$ exchange). MS. $(\mathrm{m} / \mathrm{z}, \%): 372\left(\mathrm{M}^{+}+1,11\right) ; 277(100)$; 166 (17). Anal. Calcd for $\mathrm{C}_{16} \mathrm{H}_{13} \mathrm{~N}_{5} \mathrm{O}_{2} \mathrm{~S}_{2}$ (371): C, 51.74; H, 03.53; N, 18.85; S, 17.27 (\%). Found: C, 51.64; H, 03.54; N, 18.89; S, $17.23(\%)$.

Egypt. J. Chem. 59, No. 3 (2016) 


\section{References}

1. Shelke, A.V., Bhong, B.Y. and Karade, N.N. New synthesis of 3,5-disubstituted-5Hthiazolo[3,2-a]pyrimidine via ring annulation of 3,4-dihydro pyrimidin-2(1H)-thione using alkynyl (aryl) iodonium salts. Tetrahedron Lett. 54, 600-603(2013).

2. Singh, S., Schober, A., Gebinoga, M. and Grob, G. A. Convenient method for synthesis of thiazolo[3,2-a]pyrimidine derivatives in a one-pot procedure. Tetrahedron Lett. 52(29), 3814-3817(2011).

3. Quan, Z.J., Zhang, Z., Wang, J.K., Wang X.C., Liu, Y.J. and Ji, P.Y. Efficient synthesis of $5 H$-thiazolo[3,2-a]pyrimidines from reactions of 3,4-dihydropyrimidinethiones with $\alpha$-bromoacetone in aqueous media. Heteroatom Chem. 19 (2), 149 153(2008).

4. Kulakov, I.V., Nurkenov, O.A., Turdybekov, D.M., Issabaeva, G.M., Mahmutova, A. S. and Turdybekov, K. M. Synthesis of thiazolo[3,2-a]pyrimidines based on 4aryl-substituted 3,4-dihydro-pyrimidine( $1 H)$-2-thiones and the crystal structure of ethyl 5-(2,4-dimethoxyphenyl)-7-methyl-3-oxo-3,5-dihydro- $2 H$-thiazolo-[3,2a]pyrimidine-6-carboxylate. Chem. Heterocycl. Comp. 45 (7), 856 -859(2009).

5. Fatima, S., Sharma, A., Saxena, R., Tripathi, R., Shukla, S. K., Pandey, S. K., Tripathi, R. and Tripathi, P. One pot efficient diversity oriented synthesis of polyfunctional styryl thiazolo pyrimidines and their bio- evaluation as anti malarial and anti-HIV agents. Eur. J. Med. Chem. 55, 195-204(2012).

6. Danel, K.G., Pedersen, E. B. and Nielsen, C., Synthesis and anti-HIV-1 activity of novel 2,3-dihydro-7H-thiazolo[3,2-a]pyrimidin-7-ones. J. Med. Chem. 41, 191-198(1998)

7. Coburn, R. A., Glennon, R. A. and Chmielewicz, Z. F. Mesoionic purinone analogs 7. In vitro antibacterial activity of mesoionic 1,3,4-thiadiazolo[3,2-a] pyrimidine-5,7diones. J. Med. Chem. 17, 1025-1027(1974).

8. Pan, B., Huang, R., Zheng, L., Chen, C., Han, S., Qub, D., Zhu, M. and Wei, P. Thiazolidione derivatives as novel antibiofilm agents: Design, synthesis, biological evaluation, and structure-activity relationship. Eur. J. Med. Chem. 46 (3), 819-824(2011).

9. Hammam, A.G., Fahmy, A. F.M., Amr, A. E. and Mohamed, A. M. Synthesis of novel tricyclic heterocyclic compounds as potential anticancer agents using chromanone and thiochromanone as synthons. Chem. Inform. 34 (47) (2003) .

10. Tozkoparan, B., Ertan, M., Kelicen, P. and Demirdamar, R. Synthesis and anti inflammatory activities of some thiazolo [3,2-a]pyrimidine derivatives. II Farmaco. 54, 588-593(1999)

11. Nicolle, E.J., Guyod, M.B., Namil, A. and Leclerc, G., Synthesis and antiinflammatory activities of some thiazolo [3,2-a]pyrimidine derivatives. Eur. J. Med Chem. 27, 115-120(1992).

12. Bekhit, A.A., Fahmy, H.T.Y., Rostom, S.A.F. and Baraka, A.M. Design and synthesis of some substituted $1 H$-pyrazolyl- thiazolo $[4,5-d]$ pyrimidines as anti inflammatory-antimicrobial agents. Eur. J. Med. Chem. 38, 27-36(2003).

Egypt. J. Chem. 59, No.3 (2016) 
13. Nagarajaiah, A.H., Khazi, I.H.M. and Begum, N.S. Synthesis of some new derivatives of thiazolopyrimidines and hydrolysis of its arylidene derivative. J. Chem. Sci. 127 (3), 467 -479(2015).

14. Liang, Y., Fan, S., Mo, W.Y. and He, H.W. A facile synthesis and herbicidal activities of novel fluorine-containing thiazolo[4,5-d]pyrimidin-7(6H)-ones. $J$. Fluorine Chem. 128, 879-884(2007).

15. Zhi, H., Chen, L. M., Zhang, L. L., Liu, S. J., Wan, D. C. C., Lin, H.Q. and Hu, C. 5H-Thiazolo $[3,2-a]$ pyrimidine derivatives as a new type of acetylcholinesterase inhibitors. ARKIVOC; (13), 266-277(2008)

16. Abdel-fattah, A. S. M., Negm, A. M. and Gaafar, A. M. Reactions with 6-methyl2-thiouracil: Synthesis of a new ring system dipyrimido[2,1-b:1',2'-c]thiazine; Phosphorus Sulfur Silicon Relat Elem. 72,145-156(1992).

17. Abu-Zied, Kh. M., Gaafar, A. E. M. and Aly, A. S. Synthesis and reactions of some novel azolo thienopyrimidines and thienopyrimido-as-triazines derivatives, Phosphorus Sulfur Silicon Relat Elem. 182, 447-474 (2007).

18. Aly, A. S., Abu-Zied, K. M. and Gaafar, A. E. D. M. Facile syntheses of some thieno [2, 3-d] pyrimidine derivatives. Phosphorus Sulfur Silicon Relat Elem. 183 (12), 3063-3078 (2008).

19. Walter, H. and Pfleiderer, W., Synthesis and properties of 8-substituted 2thiolumazines. Helvetica Chimica Acta, 71 (6), 1379 - 1391(1988).

20. Mosselhi, M. A. N., A convenient synthesis of novel derivatives of pyrido[2,3d] $[1,2,4]$ triazolo[4,3-a] pyrimidine-5,6-dione. Monatshefte fuer Chemie,133 (10), $1297-1304$ (2002).

21. Mosaad, S.M., Sami, M.A. and Sayed, A.I., Synthesis of certain pyrimidine derivatives as antimicrobial agents and anti-inflammatory agents. Molecules, 15, 1882-1890 (2010).

(Received 18/4/2016

accepted 12/6/2016 )

Egypt. J. Chem. 59, No. 3 (2016) 
تشييد مشتق الثيازولو[3,a]

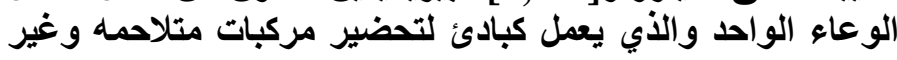
متجانسه الحلقه

علاء الدين مصطفي جعفر ، أحمد صالح علي ، خديجه محمل ابوزيد، شيماء أحمد

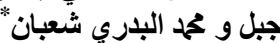

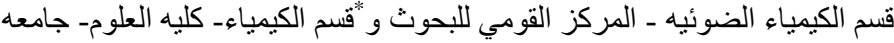
عين شمس- القاهرهـ مصر.

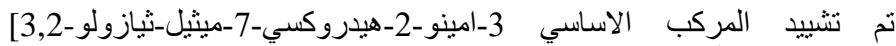

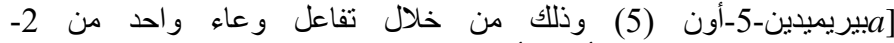

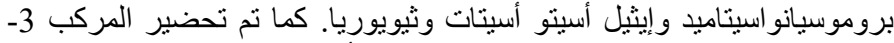

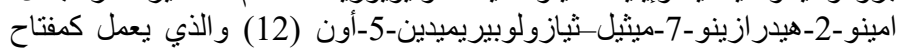

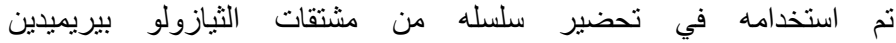
(14,15,17,18,20,22). جميع المركبات الجديده نم اثبات تركيبها الكيميائي

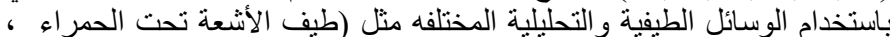
طيف الرنين النووي المغناطيسي ، مطياف الكتله ، البيانات التحليلية الدئية الديقة). 